НАУКОВИЙ ВІСНИК

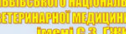

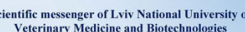

1

$\sqrt{3}$

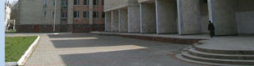

СЕРЯ: ВЕТЕРИНАРНН НАУКИ

Том 23 № 101

2021
Науковий вісник Дьвівського національного університету ветеринарної медицини та біотехнологій імені С.3. Гжицького. Серія: Ветеринарні науки

\author{
Scientific Messenger of Lviv National University \\ of Veterinary Medicine and Biotechnologies. \\ Series: Veterinary sciences
}

UDC 619:636.082.453.5.7

\title{
Efficiency test microscope "Arbor Elite" for determining the fertile period of bitches
}

\author{
P. M. Skliarov ${ }^{1}$, O. V. Holubiev ${ }^{1}$, D. D. Bilyi ${ }^{1}$, L. H. Roman ${ }^{2}$, M. O. Lieshchova ${ }^{1}$, O. M. Bobrytska ${ }^{3}$
}

${ }^{1}$ Dnipro State Agrarian and Economic University, Dnipro, Ukraine

${ }^{2}$ Odesa State Agrarian University, Odesa, Ukraine

${ }^{3}$ Kharkiv State Zooveterinary Academy, Kharkiv, Ukraine

Article info

Received 07.01.2021

Received in revised form 10.02 .2021

Accepted 11.02.2021

Dnipro State Agrarian and Economic University,

Serhii Efremov Str., 25, Dnipro, 49600, Ukraine. Tel.: +38-067-110-02-35 E-mail:skliarov.p.m@dsau.dp.ua

Odessa State Agrarian University, St. Panteleimonivs' $k a, 13$, Odessa, 65012, Ukraine.

\section{Kharkiv state zooveterinary} academy, Mala Danilivka, Dergachi district, Kharkiv region 62341, Ukraine.
Skliarov, P. M., Holubiev, O. V., Bilyi, D. D., Roman, L. H., Lieshchova, M. O., \& Bobrytska, O. M. (2021). Efficiency test microscope "Arbor Elite" for determining the fertile period of bitches. Scientific Messenger of Lviv National University of Veterinary Medicine and Biotechnologies. Series: Veterinary sciences, 23(101), 55-60. doi: 10.32718/nvlvet10110

Choosing the optimal time of insemination of she-dogs is one of the urgent problems in the reproduction of dogs, because it causes fertility and can be the cause of artificially acquired infertility or low in fertility. To this end, a number of methods are used in practice, but none of them fully meets the requirements. Therefore, the question of choosing a method for determining the optimal time of insemination of bitches remains unresolved. In this regard, the purpose of our research was to study the effectiveness of the use of the microscope "Arbor Elite" to determine the fertile period of she-dogs. The work was performed in the Clinical Diagnostic Center "Rancho" of the Faculty of Veterinary Medicine of the Dnipro State Agrarian and Economic University. The material for the study were female dogs of different breeds with a physiological course of sexual cycling. In order to determine the optimal time of insemination of bitches used test microscope "Arbor Elite", the principle of which is based on the phenomenon of salivation arborization, due to the presence of salts that crystallize as a result of increasing estrogen in the body in the stage of proestrus-estrus. There are 3 types of dried saliva after crystallization: Type I-small crystals in the form of thin stems/a large number of formed crystals "twigs". Fertilization is probable (stage of proestrus with insignificant / moderate estrogen secretion); Type II - fern leaves, crystals with a thick stem. The probability of fertilization is maximum (estrus stage with maximum estrogen production); Type III - outlines of sand or pebbles, no crystals. Fertilization is unlikely (met- / diestrus stage). It is established that the efficiency of using the test microscope "Arbor Elite" to determine the fertile period of female dogs is $85.2 \%$. However, the effectiveness of the method can be increased by differentiating endocrine pathology. In addition, the use of a test microscope "Arbor Elite" has other advantages, in particular, is simple, does not require special knowledge or training, so it can be used at home. But the main advantage is that its implementation in combination with other methods can reduce financial costs and reduce the impact of stressors (ie reduces the number of visits for sampling and cytological and hormonal tests). The method of determining the fertile period of she-dogs using a test microscope "Arbor Elite" needs further research and improvement, and its combination with other methods will optimize the diagnosis of optimal insemination time not only in bitches but also in females of different species.

Key words: female dog, optimal insemination time, saliva crystallization.

\section{Ефективність використання тест-мікроскопу “Арбор Еліт" за визначення фертильного періоду сук}

П. М. Скляров ${ }^{1}$, О. В. Голубєв ${ }^{1}$, Д. Д. Білий${ }^{1}$ Л. Г. Роман ${ }^{2}$, М. О. Лєщова ${ }^{1}$, О. М. Бобрицька ${ }^{3}$

${ }^{1}$ Дніпровський державний аграрно-економічний університет, м. Дніпро, Украӥна

${ }^{2}$ Одеський державний аграрний університет, м. Одеса, Україна 
${ }^{3}$ Харківська державна зооветеринарна академія, м. Харків, Україна

Вибір оптимального часу осіменіння сук є однією з нагальних проблем у репродукиї собак, адже обумовлює заплідненість $i$ може бути причиною штучно набутої неплідності чи малоплідності. 3 иією метою на практиці використовується низка методів, однак жоден з них не відповідає у повній мірі сучасним вимогам. Тож питання вибору методу визначення оптимального часу осіменіння сук залишається невирішеним. У зв'язку з иим мета наших досліджень полягала у дослідженні ефективності використання тест-мікроскопа у “Арбор Еліт” за визначення фертильного періоду сук. Робота виконувалася в умовах клініко-діагностичного центру “Ранчо” факультету ветеринарної медицини Дніпровського державного аграрно-економічного університету. Матеріалом для дослідження були суки різних порід з фізіологічним перебігом статевої циклічності. 3 метою визначення оптимального часу осіменіння у сук використовували тест-мікроскоп “Арбор Еліт”, принцип дії якого базується на феномені арборизації слини, обумовлений наявністю солей, які кристалізуються в результаті збільшення кількості естрогенів в організмі на стадіі проеструсу-еструсу. Розрізняють 3 типи висохлої слини після кристалізації: I тип - дрібні кристали у вигляді тонких стебел / велика кількість сформованих кристалів “гілочок”. Запліднення вірогідне (стадія проеструсу з незначною / помірною секрецією естрогенів); II тип - листя папороті, кристали з товстим стеблом. Вірогідність запліднення максимальна (стадія еструсу з максимальною продукцією естрогенів); III тип - обриси піску чи гальки, кристалів немає. Запліднення маловірогідне (стадія мет- / діеструсу). Встановлено, що ефективність використання тест-мікроскопа “Арбор Еліт” за визначення фертильного періоду сук складає 77,8-81,5\%, щчо є головним недоліком. Водночас він має певні переваги, зокрема є простим, не потребує спеціальних знань чи підготовки, тож може використовуватись в домашніх умовах. Але основний плюс полягає в тому, шо за його впровадження в поєднанні з іншими способами можна знизити фінансові витрати і зменшити дію стрес-факторів (тобто скорочується кількість візитів для взяття проб і проведення циитологічного та гормональних досліджень). Спосіб визначення фертильного періоду сук з використання тест-мікроскопа “Арбор Еліт” потребує подальших досліджень і удосконалення, а його поєднання з іншими способами дозволить оптимізувати діагностику оптимального часу осіменіння не тільки у сук, а й у самок тварин різних видів.

Ключові слова: самки собаки свійського, оптимальний час осіменіння, кристалізачія слини.

\section{Вступ}

Вибір оптимального часу осіменіння сук є однією 3 нагальних проблем у репродукції собак, адже обумовлює заплідненість і може бути причиною штучно набутої неплідності чи малоплідності (Zoldag et al., 1993; Derkach, 2011; Karnouhova, 2011). 3 цією метою на практиці використовується низка методів, як то: клініко-візуальний, вагінальна цитологія, вагіноскопія, гормональний та ін. (Hahn et al., 2017; Arlt, 2018; Labib et al., 2018; Plemjashov \& Plahova, 2018).

Однак незважаючи на такий широкий вибір, жоден iз запропонованих методів не відповідає у повній мірі сучасним вимогам. Так, Bergeron et al. вказують на те, що всі оцінені ними методики (вагінальна імпедометрія, аналіз концентрації прогестерону в сироватці крові, вагіноскопія та вагінальна цитологічна оцінка) часто давали неточні результати при індивідуальному застосуванні. Тож автори роблять висновок, що для визначення оптимального часу осіменіння у сук слід використовувати кілька методів (Bergeron et al., 2014).

Деякі автори вважають, що з метою мінімізації вартості досліджень за визначення оптимального часу осіменіння у сук достатньо проводити лише вагінальну цитологію та аналіз гормонів - лютеїнізуючого, прогестерону чи естрадіолу (Bouchard et al., 1991; Groppetti et al., 2015; Davidenko \& Ponomarenko, 2016; Hahn et al., 2017; Olğaç et al., 2017; Stekol'nikov et al., 2018).

Інші автори вважають, що виявлення овуляції та термінів осіменіння у сук повинно грунтуватися на основі концентрації гормонів, вагінальної цитології та ендоскопічного дослідження піхви (Okkens et al., 1985; Jeffcoate \& Lindsay, 1989; Rao et al., 2011).

Загалом запропоновано низку інших протоколів (Hase et al., 2000; England \& Concannon, 2002; Kustric \& Dzhonston, 2005; De Gier et al., 2006; Togoe et al., 2014), однак загальноприйнятого не існує. Тож питання вибору методу визначення оптимального часу осіменіння сук залишається невирішеним (Radohlib \& Krajevs'kyj, 2014; Lévy, 2016; Rocha Fonseca, 2016; Gürler et al., 2018; Dobrjanskaja \& Harina, 2019).

У зв'язку з цим мета наших досліджень полягала у дослідженні ефективності використання тестмікроскопа “Арбор Еліт” за визначення фертильного періоду сук.

\section{Матеріал і методи досліджень}

Робота виконувалася в умовах клінікодіагностичного центру "Ранчо" факультету ветеринарної медицини Дніпровського державного аграрноекономічного університету.

Матеріалом для дослідження були суки різних порід з фізіологічним перебігом статевої циклічності.

3 метою визначення оптимального часу осіменіння у сук використовували тест-мікроскоп “Арбор Еліт”, який складається 3 власне міні-мікроскопа та набору предметних скелець (рис. 1).

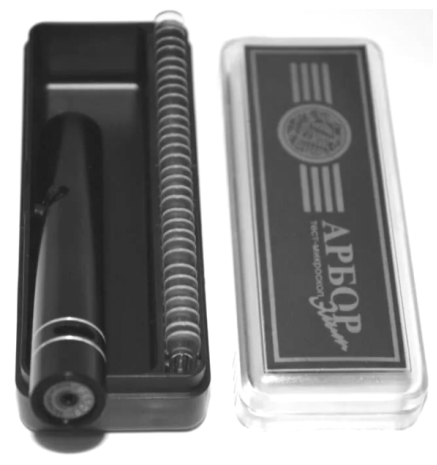

Рис. 1. Тест-мікроскоп “Арбор Еліт”

Порядок дослідження:

1. Тримаючи предметне скельце горизонтально, наносять краплю слини в спеціальне овальне поглиблення предметного скельця. Крапля не має містити бульбашок повітря і повинна змінювати форму при 
нахилі скла, не виступаючи при цьому над краями поглиблення.

2. Залишають предметне скельце в горизонтальному положенні для висихання і кристалізації слини. При нормальній температурі висихання відбувається протягом близько 15-20 хвилин.

3. Упевнившись у повному висиханні слини, вставляють предметне скло в паз тест-мікроскопу гострим кінцем так, щоб мазок слини знаходився з боку окуляра.

4. Спостерігаючи зображення в окуляр (дальній від предметного скла край), спрямовують тестмікроскоп на джерело світла і здійснюють пошук зображення та налаштування різкості. Значно спростити налаштування та збільшити зручність перегляду можна, використовуючи джерело розсіяного природного світла.

5. Аналізують зображення і результат фіксують в таблиці для індивідуального контролю статевих циклів.
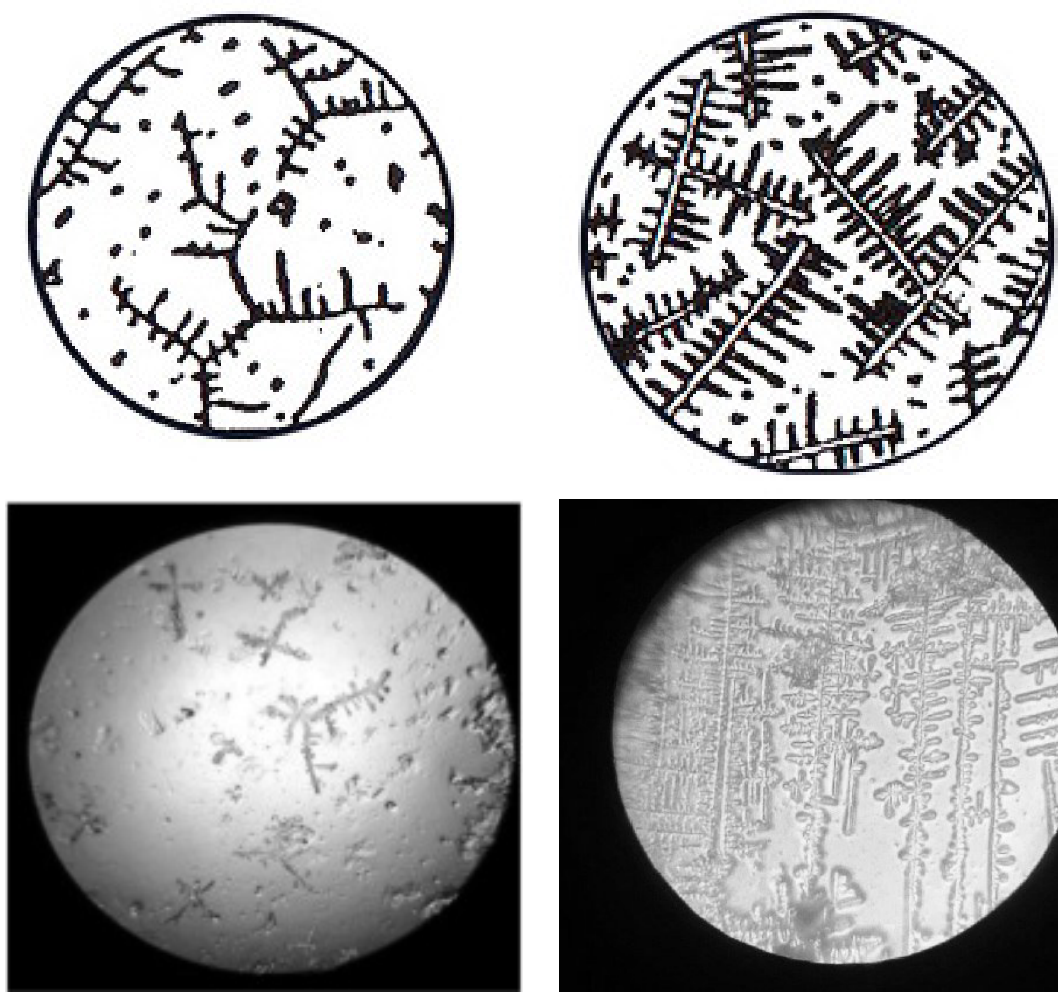

I

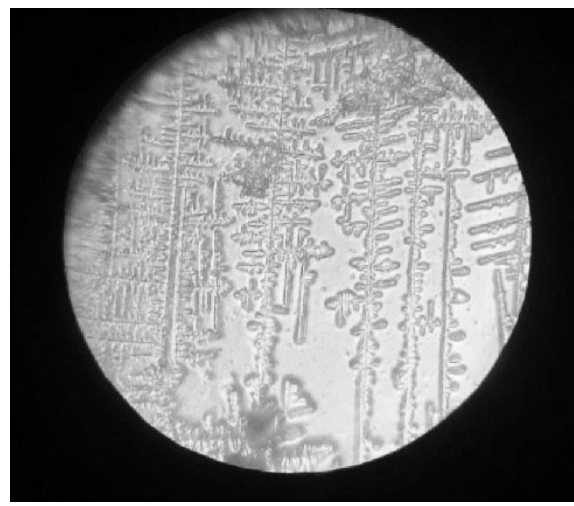

II

\section{Результати та їх обговорення}

Принцип тест-мікроскопа “Арбор Еліт” базується на феномені арборизації слини, обумовлений наявністю солей, які кристалізуються в результаті збільшення кількості естрогенів в організмі у стадії проеструсуеструсу (England, 1992; England \& Concannon, 2002; Soljannikova \& Brjuhin, 2017).

Розрізняють 3 типи висохлої слини після кристалізації (рис. 2):

I тип - дрібні кристали у вигляді тонких стебел / велика кількість сформованих кристалів "гілочок". Запліднення вірогідне (стадія проеструсу з незначною / помірною секрецією естрогенів);

II тип - у вигляді листя папороті, кристали з товстим стеблом. Вірогідність запліднення максимальна (стадія еструсу з максимальною продукцією естрогенів);

III тип - обриси піску чи гальки, кристалів немає. Запліднення маловірогідне (стадія мет- / діеструсу).
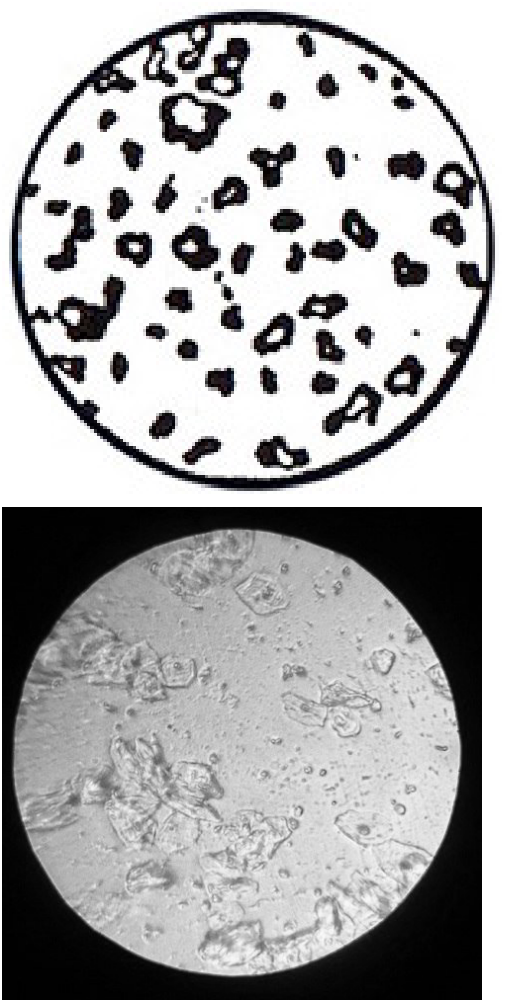

III

Рис. 2. Типи висохлої слини після кристалізації

Нами було проаналізовано загалом зразки від 27 сук і встановлено ефективність способу на рівні 85,2 \%. Однак, якщо виключити зразки сук з ендокринною патологією, то вона сягала 92,6 \% (табл. 1).

Порівняно 3 найбільш практичними і впровадженими в практику способами визначення фертильного періоду у сук використання тест-мікроскопа “Арбор Еліт” має дещо нижчу ефективність (рис. 1).

Однак ефективність способу можна підвищити, якщо диференціювати ендокринну патологію. Крім цього, використанням тест-мікроскопа "Арбор Еліт" має інші переваги. Зокрема, він є технічно простим i не потребує спеціальних знань чи підготовки, тож може використовуватися в домашніх умовах. Але основна перевага полягає в тому, що скорочується кількість візитів для взяття проб і проведення цитологічного та гормональних досліджень. Тобто, за його впровадження в поєднанні з іншими способами можна знизити фінансові витрати власників і зменшити дію стрес-факторів на сук. 


\section{Таблищя 1}

Ефективність використання тест-мікроскопу “Арбор Еліт” за визначення фертильного періоду у сук

\begin{tabular}{|c|c|c|}
\hline \multirow{2}{*}{ Показники } & \multicolumn{2}{|c|}{ Досліджено зразків } \\
\hline & $\mathrm{n}$ & $\%$ \\
\hline Вагітність & 23 & 85,2 \\
\hline Ендокринна патологія (фолікулярна кіста, гіперестронемія) & 2 & 7,4 \\
\hline Всього & 27 & 100 \\
\hline
\end{tabular}

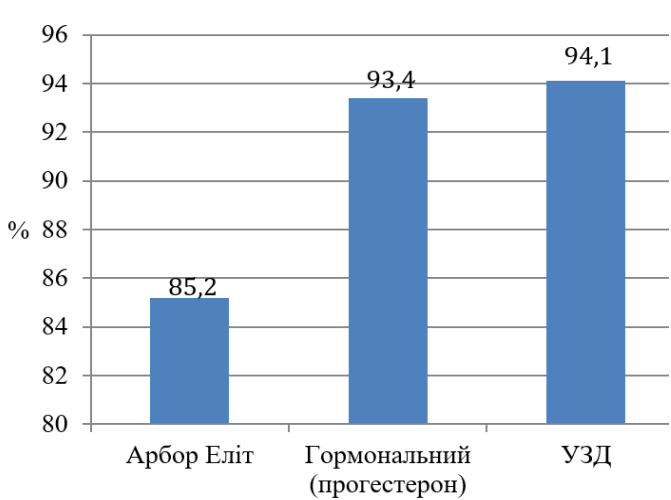

Рис. 1. Порівняльна ефективність способів визначення фертильнго періоду у сук

Кристалізація слизу з піхви і шийки матки жінок 3 утворенням деревоподібних структур вперше описана Papanicolau ще у 1942 p. (Papanicolau, 1942). Цей метод, полягає в тому, що аналізуючи під мікроскопом зміни характеру кристалізації висохлої слини (або слизу) можна 3 високим ступенем вірогідності судити про настання плодового або безплідного періоду i відповідно - підвищити ймовірність вагітності (PardoCarmona et al., 2011). Garm and Skjerven (1952) вивчали кристалізацію слизу з піхви і шийки матки корів; вони виявили, що кристали у формі гілок утворювалися під час тічки і зникали в лютеїнову фазу циклу. У жінок циклічні зміни характеру кристалізації пов'язані з секрецією естрогену і прогестерону; естроген сприяє кристалізації, тимчасом як прогестерон пригнічує іii. Zondek and Cooper зазначили, що кристалізується не тільки слиз шийки матки, а й усі слизові секрети і більшість рідин тіла, в тому числі слина (Zondek \& Cooper, 1954). Виявилося, що кристали являють собою звичайну сіль, а їхня форма залежить від наявності муцину. Напевне, процес кристалізації залежить також від присутності електролітів, білка i вуглеводів (Pardo-Carmona et al., 2011).

Таким чином, в міру збільшення естрогенів в організмі збільшується і кількість кристалів в слині, причому в дні овуляції кристали набувають форми, що нагадує папороть. Максимальний ступінь кристалізації спостерігається за 2-3 доби до передовуляторного піку лютеїнізуючого гормону. Цей метод отримав назву “арборизаціi”, від латинського “arbor” - дерево (Raeside \& McDonald, 1959; England, 1992; England \& Allen, 1989; Voroncova, 2008; Masalovych et al., 2018).

Чутливість і специфічність тесту з кристалізацією слини вказується як 53 та 72 \% (Braat et al., 1998). На підставі цих особливостей були розроблені готові тест-системи, що дозволяють швидко, просто і недорого визначити період, сприятливий для запліднення.
На думку ряду вчених, метод досить суб'єктивний і фізіологічно недосконалий, на що вказує можливість кристалізації слизу під час ановуляторних статевих циклів та за кіст яєчників (Shabanah, 1960; Bordjugov et al., 2013; Thomas, 2013; Plemjashov \& Plahova, 2018). Інші автори вважають, що необхідні подальші дослідження для підвищення його ефективності (England \& Allen, 1989; Perez et al., 2005; PardoCarmona et al., 2011).

\section{Висновки}

Вибір оптимального часу осіменіння сук $є$ однією 3 нагальних проблем у репродукції собак, адже обумовлює заплідненість і може бути причиною штучно набутої неплідності чи малоплідності. 3 цією метою на практиці використовується низка методів, однак жоден 3 них не відповідає у повній мірі сучасним вимогам. Тож питання вибору методу визначення оптимального часу осіменіння сук залишається невирішеним.

У зв'язку з цим мета наших досліджень полягала у дослідженні ефективності використання тестмікроскопа “Арбор Еліт” за визначення фертильного періоду сук.

Встановлено, що ефективність використання тестмікроскопа “Арбор Еліт” за визначення фертильного періоду сук складає 85,2 \%. Однак ефективність способу можна підвищити, якщо диференціювати ендокринну патологію. Крім цього, використанням тестмікроскопа “Арбор Еліт” має інші переваги, зокрема $\epsilon$ простим, не потребує спеціальних знань чи підготовки, тож може використовуватись в домашніх умовах. Але основна перевага полягає в тому, що за його впровадження в поєднанні з іншими способами можна знизити фінансові витрати і зменшити дію стресфакторів (тобто скорочується кількість візитів для взяття проб і проведення цитологічного та гормональних досліджень).

Перспективи подальших досліджень. Спосіб визначення фертильного періоду сук 3 використання тест-мікроскопа “Арбор Еліт” потребує подальших досліджень і удосконалення, а його поєднання 3 іншими способами дозволить оптимізувати діагностику оптимального часу осіменіння не тільки у сук, а й у самок тварин різних видів.

Відомості про конфлікт інтересів. Автори стверджують про відсутність конфлікту інтересів щодо їх вкладу та результатів досліджень. 


\section{References}

Arlt, S. (2018). Canine ovulation timing: A survey on methodology and an assessment on reliability of vaginal cytology. Reproduction in Domestic Animals, 53, 53-62. doi: 10.1111/rda.13352.

Bergeron, L. H., Nykamp, S. G., Brisson, B. A., Madan, P., Sears, W., \& Gartley, C. J. (2014). Vaginal impedometry for detection of optimal breeding time in bitches. Journal of the American Veterinary Medical Association, 245(12), 1360-1366. doi: 10.2460/javma.245.12.1360.

Bordjugov, K. S., Bordjugova, S. S., \& Kot, V. S. (2013). Rizni metody vyznachennja ovuljacii' u sobak [Different methods for determining ovulation in dogs]. Visnyk Poltavs'koi' derzhavnoi' agrarnoi' akademii', 1, 116-119 (in Ukrainian).

Bouchard, G. F., Solorzano, N., Concannon, P. W., Youngquist, R. S., \& Bierschwal, C. J. (1991). Determination of ovulation time in bitches based on teasing, vaginal cytology, and elisa for progesterone. Theriogenology, 35(3), 603-611. doi: 10.1016/0093691x(91)90456-n.

Braat, D., Smeenk, J., Manger, A., Thomas, C., Veersema, S., \& Merkus, J. (1998). Saliva test as ovulator predictor. Lancet, 352, 1283-1284. doi: 10.1016/s0140-6736(05)70490-6.

Davidenko, N. G., \& Ponomarenko, V. P. (2016). Issledovanie urovnja progesterona $\mathrm{v}$ krovi metodom immunofermentnogo analiza dlja opredelenija srokov ovuljacii u suk [Study of the level of progesterone in the blood by enzyme immunoassay to determine the timing of ovulation in bitches]. Zhivotnovodstvo i veterinarnaja medicina, 3(22), 21-24 (in Russian).

De Gier, J., Kooistra, H. S., Djajadiningrat-Laanen, S. C., Dieleman, S. J., \& Okkens, A. C. (2006). Temporal relations between plasma concentrations of luteinizing hormone, follicle-stimulating hormone, estradiol-17 $\beta$, progesterone, prolactin, and $\alpha$-melanocyte-stimulating hormone during the follicular, ovulatory, and early luteal phase in the bitch. Theriogenology, 65(7), 13461359. doi: 10.1016/j.theriogenology.2005.08.010.

Derkach, S. S., Val'chuk, O. A., Ljubec'kyj, J. V., \& Kunak, J. V. (2011). Efektyvnist' vykorystannja metodiv vyznachennja optymal'nogo chasu osimeninnja suk [The effectiveness of methods for determining the optimal time of insemination of bitches]. Naukovyj visnyk L'vivs'kogo nacional'nogo universytetu veterynarnoi' medycyny ta biotehnologij imeni S.Z. G'zhyc'kogo, 4(1(50), 84-89 (in Ukrainian).

Dobrjanskaja, M. S., \& Harina, L. V. (2019). Opredelenie optimal'nogo sroka vjazki sobak [Determining the optimal mating time for dogs]. In: Molodezhnaja nauka - garant innovacionnogo razvitija APK, 69-73 (in Russian).

England, G., \& Concannon, D. W. (2002). Determination of the optimal breeding time in the bitch-basic considerations. In: P.W. Concannon, G. England, J. Verstegen and C. LindeForsberg (Eds.). Recent advances in Small Animal Reproduction. International Veterinary Information Service, Ithaca, New York, USA.
England, G. C. W. (1992). Vaginal cytology and cervico vaginal mucus arborisation in the breeding management of bitches. J. Small Anim. Pract., 33(12), 577582. doi: 10.1111/j.1748-5827.1992.tb01060.x.

England, G. C. W., \& Allen, W. E. (1989). Crystallization patterns in anterior vaginal fluid from bitches in oestrus. J. Reprod. Fertil., 86(1), 335-339. doi: $10.1530 / \mathrm{jrf} .0 .0860335$.

Garm, O., \& Skjerven, O. (1952). Studies on cervical mucus for early diagnosis of pregnancy and endocrine changes in the reproductive cycle in domestic animals. Nordisk Veterinaermedicin, 4, 1098-1103.

Groppetti, D., Aralla, M., Bronzo, V., Bosi, G., Pecile, A., \& Arrighi, S. (2015). Periovulatory time in the bitch: What's new to know?: Comparison between ovarian histology and clinical features. Animal reproduction science, 152, 108116. doi: 10.1016/j.anireprosci.2014.11.008.

Gürler, H., Koldas, E., Binli, F., \& Akçay, A. (2018). Efficiency of vaginal electrical impedance to determine the stage of the reproductive cycle in bitches. Med Weter., 74(3), 179-181. doi: 10.21521/mw.6080.

Hahn, S. E., Jo, Y. K., Jin, Y. K., \& Jang, G. (2017). Timing of fertile period for successful pregnancy in American Bully dogs. Theriogenology, 104, 49-54. doi: 10.1016/j.theriogenology.2017.07.034.

Hase, M., Hori, T., Kawakami, E., \& Tsutsui, T. (2000). Plasma LH and progesterone levels before and after ovulation and observation of ovarian follicles by ultrasonographic diagnosis system in dogs. Journal of Veterinary Medical Science, 62(3), 243-248. doi: 10.1292/jvms.62.243.

Jeffcoate, I. A., \& Lindsay, F. E. (1989). Ovulation detection and timing of insemination based on hormone concentrations, vaginal cytology and the endoscopic appearance of the vagina in domestic bitches. Journal of Reproduction and fertility, 39, 277-287. URL: https://pubmed.ncbi.nlm.nih.gov/2621729.

Karnouhova, O. M. (2011). Likvidacija besplodija u suk [Elimination of infertility in bitches]. Vestnik Donskogo gosudarstvennogo agrarnogo universiteta, 1, 45-50 (in Russian).

Kustric, M. V. R., \& Dzhonston, S. D. (2005). Ispol'zovanie progesterona syvorotki krovi dlja reguljacii vremeni ovuljacii u suk [Use of serum progesterone to regulate ovulation time in bitches]. In: Bonagura JD (Ed.). Sovremennyj kurs veterinarnoj mediciny Kirka [Kirk's modern veterinary medicine course]. Akvarium-Print, Moskva, 1004-1005 (in Russian).

Labib, F. M., Mansour, H. H., Mahdy, A. B., \& Abdallah, A. A. (2018). Predicting the optimal time of breeding and the possible approaches for treatment of some estrus cycle abnormalities in bitches. Slovenian Veterinary Research, 55, 125-135.

Lévy, X. (2016). Videovaginoscopy of the canine vagina. Reprod. Dom. Anim., 51(1), 31-36. doi: 10.1111/rda.12785.

Masalovych, Y. S., Val'chuk, O. A., \& Derkach, S. S. (2018). Osoblyvosti arboryzacii' sekretu slyzovyh obolonok u koriv [Features of arborization to the secretion of mucous membranes in cows]. Naukovi 
dopovidi NUBiP Ukrai'ny, 1(71). doi: 10.31548/dopovidi2018.01.026 (in Ukrainian).

Okkens, A. C., Dieleman, S. J., \& Vogel, F. (1985). Determination of the ovulation period in the dog. A comparison of the rapid progesterone assay, vaginoscopy and vaginal cytology. In: Proc. Voorjaarsdagen (pp. 26-27). Royal Netherlands Vet. Assoc.

Olğaç, K. T., Akçay, E., Çil, B., Uçar, B. M., \& Daşkın, A. (2017). The use of infrared thermography to detect the stages of estrus cycle and ovulation time in anatolian shepherd dogs. J Anim Sci Technol, 59(1), 21. doi: 10.1186/s40781-017-0146-4.

Papanicolau, G. N. (1942). A new procedure for staining vaginal smears. Science, 95, 438-439. doi: 10.1126/science.95.2469.438.

Pardo-Carmona, B., Moyano, M.R., Fernández-Palacios, R., Pérez-Marín, C. C. (2010). Kristallizacija sljuny kak sposob opredelenija optimal'nogo vremeni vjazki suk [Saliva crystallization as a way to determine the optimal mating time for bitches]. Journal of Small Animal Practice (Russian edition), 51, 437-442. doi: 10.1111/j.1748-5827.2010.00967.x (in Russian).

Perez, C. C., Rodriguez, I., Dorado, J., \& Hidalgo, M. (2005). Use of ultrafast Papanicolau stain for exfoliative vaginal cytology in bitches. Veterinary Record, 156, 648-650. doi: 10.1136/vr.156.20.648.

Plemjashov, K. V., \& Plahova, A. I. (2018). Metody opredelenija vremeni vjazki u sobak [Methods for determining mating time in dogs]. Mezhdunarodnyj vestnik veterinarii, 2, 106-112 (in Russian).

Radohlib, G. M., \& Krajevs'kyj, A. J. (2014). Zminy klitynnogo skladu vaginal'nyh mazkiv suk u rizni fazy statevogo cyklu [Changes in the cellular composition of vaginal swabs of bitches in different phases of the sexual cycle]. Visnyk Sums'kogo nacional'nogo agrarnogo universytetu, 6, 199-202 (in Ukranian).

Raeside, J. I., \& McDonald, M. F. (1959). Arborization of cervical mucus in the ewe. Journal of Endocrinology, 18(4), 350-358.

Rao, K. S., Raju, K. G. S., \& Reddy, K. C. S. (2011). Vaginal cytology, vaginoscopy and progesterone profile: breeding tools in bitches. Iraqi Journal of Veterinary
Sciences, 25(2), 51-54. doi: 10.33899/ijvs.2011.5656.

Rocha Fonseca, B. D. C. (2016). Estudio comparativo para detección de ovulación en hembras canina por citología vaginal, progesterona sèrica y detector draminski. Julio-Diciembre, 2015 (Doctoral dissertation, Universidad Nacional Agraria).

Shabanah, E. H. (1960). Arborizations in cervical smears. American Journal of Obstetrics \& Gynecology, 79(2), 413-414. doi: 10.1016/0002-9378(60)90231-3.

Soljannikova, D. R., \& Brjuhin, G. V. (2017). Osobennosti arborizacii smeshannoj sljuny samok krys $\mathrm{v}$ raznye fazy polovogo cikla [Features of arborization of mixed saliva in female rats in different phases of the sexual cycle]. Mezhdunarodnyj nauchno-issledovatel'skij zhurnal, 2(56), 36-46 (in Russian).

Stekol'nikov, A. A., Plemjashov, K. V., Ladanova, M. A., \& Mebonija, E. G. (2018). Opredelenie srokov ovuljacii u suk [Determining the timing of ovulation in bitches]. Voprosy normativno-pravovogo regulirovanija v veterinarii, 2, 61-63. doi: 10.17238/issn20726023.2018.2.61 (in Russian).

Thomas, P. (2013). Breeding management and ovulation timing in the bitch. In: World Small Animal Veterinary Association World Congress Proceedings (March 6-9, 2013). URL: https://www.vin.com/apputil/ content $/$ defaultadv1.aspx?pId=11372\&id=5709846.

Togoe, D., Pascal, M., Vitalaru, A., Costea, R., \& Birtoiu, A. (2014). Optimization of reproductive biotechnologies in bitches by improving the protocols regarding establishment of the ovulation timing. Scientific Works. Series C. Veterinary Medicine, 60(2), 65-69.

Voroncova, A. V. (2008). Vozmozhnye metody diagnostiki ovuljacii [Possible methods for diagnosing ovulation]. Ural'skij medicinskij zhurnal, 2, 75-80 (in Russian).

Zoldag, L., Kecskemethyl, S., \& Nagy, P. (1993). Heat progesterone profiles of bitches with ovulation failure. Journal of Reproduction and Fertility, 47, 562-563.

Zondek, B., \& Cooper, K. (1954). Cervical mucus in pregnancy: Inability of estrogen to produce arborization in pregnancy and its clinical significance. Obstetrics \& Gynecology, 4(5), 484 491. 